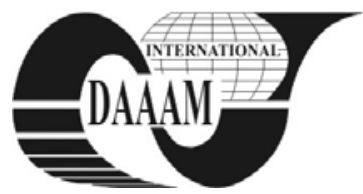

Annals of DAAAM for 2011 \& Proceedings of the 22nd International DAAAM Symposium, Volume 22, No. 1, ISSN 1726-9679 ISBN 978-3-901509-83-4, Editor B. Katalinic, Published by DAAAM International, Vienna, Austria, EU, 2011 Make Harmony between Technology and Nature, and Your Mind will Fly Free as a Bird Annals \& Proceedings of DAAAM International 2011

\title{
INNOVATION IN INDUSTRY IN SLOVAK REPUBLIC
}

\section{CHATRNUCHOVA, L[ucia]; MARKOVA, P[etra]; PRAJOVA, V[anessa] \& SABLIK, J[ozef]}

\begin{abstract}
The main target of this article is to describe the current situation in Slovak industry. The current global economic crisis is forcing the industrial companies to find solutions and ways how to reduce negative impacts, sustain development, competitiveness, production and employment (Szabó et al., 2010). One of the common answers is savings and cost reductions. But will the steps and measures, oriented to saving and cost reduction, sufficient for company stabilization, development and preparation for post - crisis period? It is necessary to think of innovation. One of the possible innovation is also monitoring the economic benefits of the investment project also monitoring social benefits.

Key words: innovation, investment, Slovak industry, social effectiveness
\end{abstract}

\section{INTRODUCTION}

The worldwide industry especially the automotive industry moves up the higher speed. It is the industry which is based on its history, skills and new knowledge, international cooperation, human resource development, innovation, research and development and, finally, itself the car production realization. All these areas are still in process and determinate a new direction for the global automotive industry development.

The Slovak industry has become highly global industry, which is faced with a number of global challenges and opportunities. Between the major challenges and opportunities may include:

- $\quad$ climate changes and natural resources reduction

- social responsibility

- $\quad$ sustainable mobility and urbanization

- health and safety

- demographic changes and employment

- $\quad$ innovation and new green technologies

- $\quad$ the global financial and economic crisis

- development of the new economies and markets.

European Union (EU) is the largest motor vehicles' producers in the world. The automotive industry has the main impact on GDP growth in Slovakia. It is a large employer of skilled labour and the main knowledge and innovation driver. Automotive industry operates in Europe and also in Slovakia as the largest private investor in the field of research and development. It also significantly contributes to gross domestic product in the EU. Therefore, it has the significant meaning for Europe's prosperity. In connection with the car industry development, the EU has recently launched a European strategy for cleaning energy efficient vehicles, which should provide appropriate and technologically neutral policy framework for clean and energy efficient vehicles. The strategy, inter alia, dedicates to the issues concerning the promotion of research and innovation in green technology, jobs, global aspects of recycling, infrastructure, etc.

\section{INNOVATION PROCESS}

The continual growth of competitiveness in manufacturing is possible to ensure with continuous upgrading of its technical and technological level. Therefore it is necessary that business subjects could continually invest in the reconstruction and development of their technological bases. Despite the current financial crisis in the world, which also affected the automotive industry and many strong supplier companies, the world of further innovations is continuously running. Many car manufacturers had to accede to the emergency plan, causing the closing of businesses, reduction of production and layoffs. Despite these unflattering reports we can say that the development of new products, processes, technologies and services will continually advancing nature. Increased emphasis on activities related to research and development, innovation, education is now highly topical issue in society, automotive and engineering companies, research institutions and universities in particular. A search option for financing solutions for both international and domestic projects, is one possibility how to visible and to show their innovative and creative abilities. Slovakia needs to be innovated, researched and developed country with highly educated human potential, which represents a major challenge for the present, and also the view for a successful future.

Innovation is the engine of the industry (Szabó et al., 2010). The ability to innovate, to respond flexibly on market requirements, deliver new products, improve manufacturing and assembly processes are factors that should be included among the measures and activities for crisis mitigation in enterprises. It can also be the springboard for a better view. In most businesses are faced with product innovation, but it is important to innovate and improve

- $\quad$ the production processes

- assembly processes

- administrative - management processes.

Innovation processes represent a set of activities which lead to successful production, implementation and exploitation of novelty in the economic, social and environmental fields. Innovation contributes to economic and social development, influencing production and environmental protection. Innovations are the result of research activities, purchase of know - how and licenses, business activity (investment in new equipment, organizational measures, use of information technologies), or other activities (education, social activities, activities in health care, etc.).

\section{DECISION ON INVESTMENT}

Decision in the field of investment is considered one of the most important because it directly determinates the future direction of the company. It is a decision that is characterized by long duration, severe correction; with the need of taking into account the time and risk factors, consistent with respecting the 
basic strategic business objectives. Systemic assessment of the effectiveness of investment projects must be conducted with respect to their seriousness and a series of related, difficult to quantify movement characteristics that should be taken into account. Effectiveness allocation of capital investment projects requires evaluation methods and investment rules that allow deciding whether individual investments contribute to achieving business goals. At present, the companies focus not only on economic efficiency, but are increasingly gaining ground, and other aspects of the environmental and social efficiency.

\subsection{The social effectiveness of the investment}

Europe has a long been discussion about how to make the business to bring the benefit not only the firm itself, but also the wider public and the community. This above-mentioned topic is becoming more and more important and debated in Slovakia. The social effectiveness of investment is a society-wide phenomenon that is well supported in the Slovak legislation (No. 387/1996, 100/1995, 233/2008, 575/2001, 172/2005 Coll. of law, etc.), international framework agreements, the ratification agreements, etc. The expertise of the social effectiveness itself follows if the mentioned investment shares the following effects see figure 1 (Marková \& Hatiar, 2009):

\begin{tabular}{|ll|}
\multicolumn{2}{|c|}{ Social effects } \\
\hline Company & Employee \\
\hline $\begin{array}{l}\text { - creation of job } \\
\text { opportunities }\end{array}$ & $\begin{array}{l}\text { - employee's needs (wages, } \\
\text { education, insurance, } \\
\text { working conditions) }\end{array}$ \\
\hline $\begin{array}{l}\text { - loss reduction as a result } \\
\text { of fluctuation }\end{array}$ & - stability of jobs \\
\hline $\begin{array}{l}\text { - cost reduction from } \\
\text { sickness absence }\end{array}$ & $\begin{array}{c}\text { - improvement of working } \\
\text { environment }\end{array}$ \\
\hline $\begin{array}{l}\text { - loss reduction from } \\
\text { injuries }\end{array}$ & - increase in work culture \\
\hline - reduction of faulty pieces & \\
\hline
\end{tabular}

Fig. 1. Social effects of investment

The social effectiveness of investments lays stress on human capital company. In the sigh of company, the social efficiency can be understood not as profit maximization, but as the creation of added social value and social inclusion of workers and profit reinvestment into the development of major social company targets (Sablik, 2010). Social responsibility includes itself the effective and responsible approach to investment components developed for the company, relationships with employees, creativity and labor sustainability and interest in the environment. Social effectiveness introduces the concept, under which companies or organizations are trying to integrate the universal interests (such as interest of government, business, employees, customers, suppliers, shareholders etc.) into their activities.

Social effects represent social contributions for subjects' involved (state, municipality, company, and employee) with the common interaction. A company in its actions carries out measurements resulting from legal regulations and norms. The fact that the enterprise evaluates investments also from the point of view of social effects is an expression of its business ethics and adopted ethics code. The company through social effectiveness contributes to the creation of positive socialpsychological environment (beyond legal obligations). The company is acted as an element - a mediator, between the state and the employer (Sablik, 2010). The state through the company supports directly the employer. The state through its investment policy subsidizes companies which create new jobs, improve the working conditions, safety and health protection, work injuries, work culture etc.
3.2 The evaluation of the social effectiveness of investment in companies operated in Slovak market

At present, in Institute of Industrial Engineering, Management and Quality MTF STU Trnava, in ongoing dissertation thesis is carrying out the research which task is to (Chatrnúchová et al., 2010):

- identify topicality issue and needs of its solutions

- find out the status quo of investment complex evaluation

- follow up the benefits of investment

- assess the effects of social investment.

Research focuses on 150 medium and large industrial companies operated on Slovak market. Questionnaires were distributed electronically (electronic questionnaires sent by email) and they are collected the same way. One questionnaire always represents the situation in a one company. Current return on questionnaires is $26,67 \%$ (Chatrnúchová et al., 2010). The research results will be used to create a comprehensive methodology for assessing the effectiveness of investment projects. At present, a comprehensive assessment of the effectiveness of investment projects is to evaluate the economic, environmental efficiency. This methodology will be complemented by monitoring of social efficiency. Implementation of the proposed methodology into practice will be provided through the cooperation with enterprises.

\section{CONCLUSION}

Each company is the part of a society. It operates in a particular environment, which affects and shapes the company and vice - versa. This mechanism cannot run properly separately, so if the company wants to be successful in long term business, it has to take account to its surrounding, be interested in the social problem. Each enterprise must take account that excellent performance can give only satisfied and motivated employees. The investments, which have the social benefits, help the company to be „different „and thus increase its competitiveness. Therefore, the company would be interested to follow not only the economic and environmental aspects of investments but also social aspects of investments and their benefits for society as a whole.

\section{REFERENCES}

Chatrnúchová, L., Ondrušková, O., Sablik, J. (2010). Methods for social efficiency evaluation of the investment, Proceedings of InvEnt 2010, Žilina, ISBN 978-80-8940112-3. pp.. 164--167. University of Žilina, Žilina

Marková, P., Hatiar, K. (2009). The influence of ergonomics on quality of work life. In: CO-MAT-TECH 2009. Industrial Engineering, Management and Quality for 21st century. Proceedings of the 17th International Science Conference, 2009. Trnava: ISBN 978-80-8096-100-8. pp. 246-252 AlumniPress

Sablik, J. (2010). Management of investment development of the company, non - publicated materials. Slovak University of Technology, Trnava, 2010

Szabó, P., Chatrnúchová, L., Sablik, J., Vičíková, J. (2010). Investment decisions in conditions of continual change. Proceedings of MMK 2010, 2010. Hradec Králové. ISBN 978-80-86703-41-1. pp. 926--930. Magnanimitas, Hradec Králové

*** (2011) http://www.webnoviny.sk/automagazin/automobilo vy-priemysel-vyzvytrendy/242348-clanok.html Accessed: 2011-09-15

*** (2011) http://www.autopriemysel.sk/index.php? option=com_content\&task=view\&id=203\&Itemid=115 Accessed: 2011-09-15

*** (2011) http://www.deloitte.com/view/sk_SK/sk/ spravodajstvo/tlacovespravy/c53fa68c4d101210VgnVCM1 00000ba42f00aRCRD.htm Accessed: 2011-09-15 